\title{
A new species of Calacarus Keifer (Acari: Eriophyidae) on papaya in northeastern Brazil
}

\author{
CARLOS H.W. FLECHTMANN ${ }^{1}$, GILBERTO J.DE MORAES ${ }^{2} \&$ FLÁ VIA R. BARBOSA ${ }^{3}$ \\ ${ }^{I}$ CNPq-Brazil Researcher, Universidade de São Paulo / ESALQ, Departamento de Entomologia, Fitopatolo- \\ gia e Zoologia Agrícola, 13418-900 Piracicaba, SP, Brasil. E-mail: chwflech@carpa.ciagri.usp.br \\ ${ }^{2}$ CNPq-Brazil Researcher, Universidade de São Paulo / ESALQ, Departamento de Entomologia, Fitopatolo- \\ gia e Zoologia Agrícola, 13418-900 Piracicaba, SP, Brasil.E mail: gjmoraes@carpa.ciagri.usp.br \\ ${ }^{3}$ EMBRAPA - Semi-Árido, C.P. 23, 56.300-970 Petrolina, PE, Brasil. E-mail: flavia@cpatsa.embrapa.br
}

\begin{abstract}
Calacarus flagelliseta n. sp. (Acari: Prostigmata: Eriophyidae) is described from northeastern Brazil based on adults of both sexes collected from papaya leaves.
\end{abstract}

Key words: Acari, Eriophyidae, Calacarus, papaya, taxonomy.

\section{Introduction}

Circa thirty species are presently considered to belong to the genus Calacarus Keifer, 1940. Two of those putative species have been reported on Carica papaya L.: Calacarus brionesae Keifer, 1963, and C. citrifolii Keifer, 1955 (van der Merwe \& Coates 1965). Two additional records of $C$. citrifolii on papaya (Jeppson et al. 1975; Meyer \& Craemer 1999) are probably based on the report of van der Merwe \& Coates (1965). C. brionesae has been reported only on papaya. $C$. citrifolii has been reported on 28 plant species belonging to 21 families (J. Amrine Jr., personal communication); however, this relatively large number of despaired hosts seems to indicate that those records may actually refer to more than one Calacarus species (Jeppson et al. 1975).

Calacarus citrifolii has been reported to cause bronzing of papaya leaves (Meyer \& Cramer 1999), whereas $C$. brionesae has been reported to cause edge rolling of the leaves of this plant and white spots along the rolls. The third author of this paper recently found a restricted area of papaya plantation in northeastern Brazil showing severe upward rolling followed by necrosis and death of leaves. Those symptoms were attributed to a new 
species of Calacarus, found in large numbers on plants showing these symptoms. This new species is here described.

Measurements are given in micrometers, and unless otherwise specified refer to the length of each structure. For females, each measurement of the holotype precedes the corresponding range for the paratypes. Some measurements of the holotype could not be taken because of the position it was mounted.

\section{Calacarus flagelliseta n. sp. (Figs. 1, 2)}

DIAGNOSIS - A robust, large Calacarus, with 6-rayed empodia, without prodorsal shield tubercles and setae, prodorsal shield design unique, opisthosomal and genital setae long.

FEMALE - $(\mathrm{n}=6)$ Idiosoma spindle-shaped, 242 (220-246), 84 (84-91) wide, in life brownish with white longitudinal wax bands. Gnathosoma downcurved, (38-45), basal setae 5 (4-5), antapical setae 11 (10-12), chelicerae 39 (32-39). Prodorsal shield 54 (5457), 75 (67-75) wide, anterior lobe broad, rounded and medially slightly emarginate, tubercles and setae absent. Shield design a network: median line present only as very short segments on anterior lobe and to rear; admedian lines curved, interbranching, delimiting a pair of quadrangular cells on anterior lobe and two elongate cells on shield. Hindmost median cell flanked on each side by one irregular pentagonal cell. Lateral design a line of cells. Legs without genual setae II; legs I 39 (37-39); femora 12 (11-12), femoral setae (bv) 18 (16-18); genua 6 (4-6), genual setae $\left(l^{\prime \prime}\right) 29$ (26-29); tibiae 9 (9-10), distally and axially with a row of 6 longitudinal small spines, tibial setae $\left(l^{\prime}\right) 10(6-10)$; tarsi 8 (8-9), solenidia 11 (10-11), slightly enlarged distally, empodia 9 (8-11), 6-rayed, dorsal setae $\left(f t^{\prime}\right) 30$ (2830 ), lateral setae $\left(f t^{\prime \prime}\right) 32$ (31-32), unguinal setae $\left(u^{\prime}\right) 9$ (8-10). Legs II 36 (33-36); femora 12 (9-12), bv 18 (16-19); genua 5 (4-5), $l$ " absent; tibiae 7 (7-8), with a row of ca. 6 small, longitudinal spines distally and axially; tarsi 8 (8), solenidia 13 (11-13), empodia 11 (911), 6-rayed, $f t^{\prime} 16$ (11-16), $f t^{\prime \prime} 29$ (27-30), $u^{\prime} 11$ (9-11). Coxae: coxae I contiguous centrally; coxae I and II with a few short lines and granules. Coxae I (or coxisternal plates I) anteriorly continuous with the granulated hypostome. Coxal setae I (1b) 13 (11-15), 19 (18-19) apart; coxal setae II (1a) 18 (18-31), 12 (11-13) apart; coxal setae III (2a) 53 (5369), 35 (33-36) apart. Coxigenital area with 8 (8-9) annuli, microtuberculate. Genitalia 29 (27-32) wide, 22 (20-23) wide, epigynium with faint, short, longitudinal lines basally, smooth distally. Genital setae (3a) 56 (56-65), extending posteriorly almost to bases of setae $e$. Opisthosoma with five dorsal longitudinal wax bearing ridges: median ridge distinct to approximately dorsad of bases of setae $f$, lateral ridges distinct to dorsad of bases of setae $e$ and submedian ridges of intermediate length. Lateral setae (c2) 86 (84-92), reaching bases of setae $e$; on annulus 3 (3-4); ventral setae I (d) 79 (77-89), 58 (55-60) apart, on annulus 21 (18-21); ventral setae II (e) 55 (54-63), 29 (27-30) apart, on annulus 46 (39-46); ventral setae III (f) 37 (37-48), 32 (30-32) apart, on annulus 69 (60-69) or 10th (8th-10th) from rear. Total ventral annuli 78 (70-78); microtubercles small, beadlike, on 
ring margins. Total dorsal annuli 72 (68-73), smooth. Caudal setae (h2) 70 (70-89); accessory setae $(h l)$ absent.

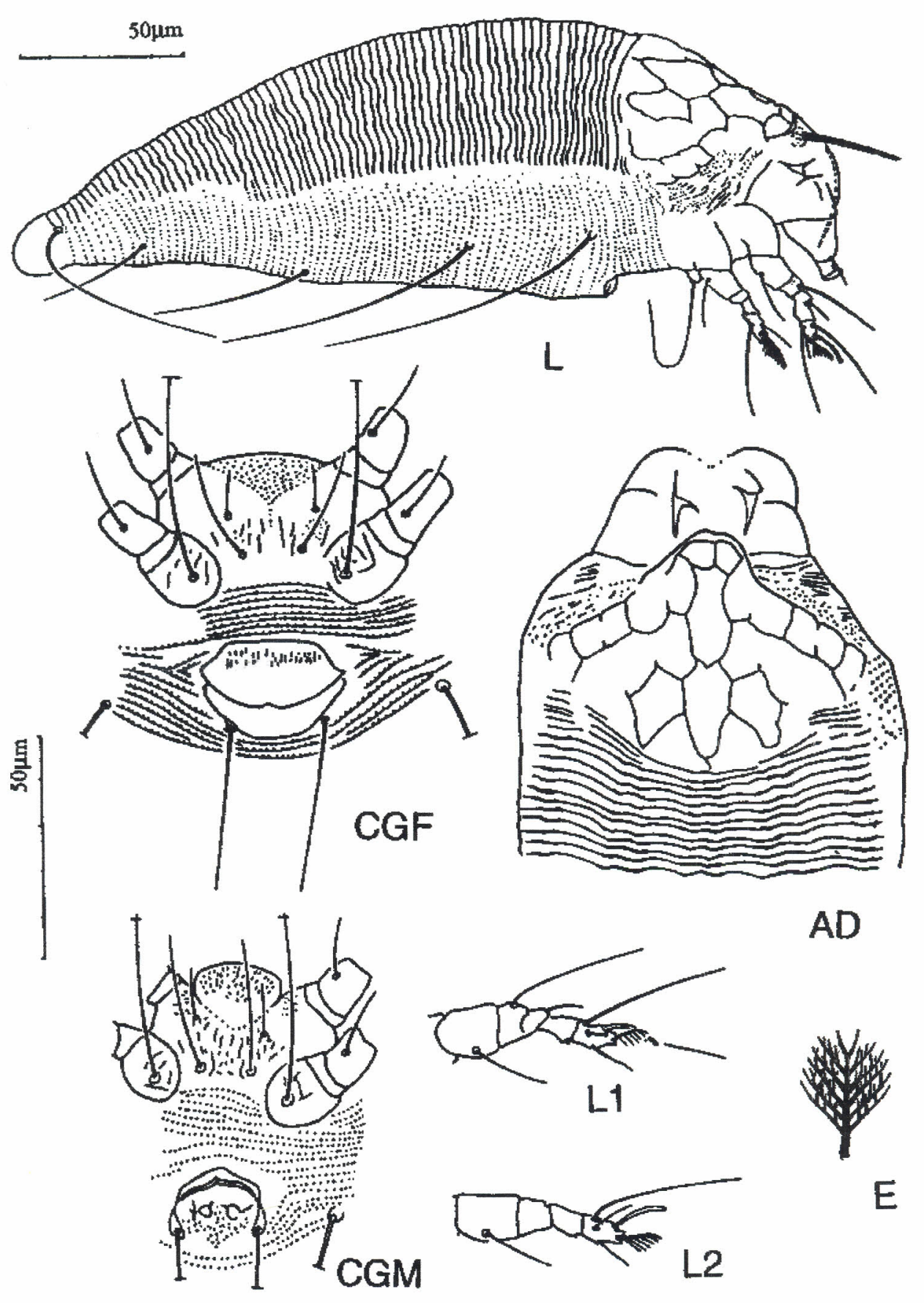

FIGURE 1. Calacarus flagelliseta n.sp. AD, Anterior dorsal aspect; CGF, coxigenital area of female; CGM, coxigenital area of male; E, empodium; L, lateral habitus; L1, leg I; L2, leg II. 
MALE - $(n=4)$. Smaller than female, 185-201, 71-79 wide. Gnathosoma 40, basal setae 4-5, antapical setae 6-11; chelicerae 27-31. Prodorsal shield 46-48, 62-67 wide. Legs: legs I 33-36; femora 10-11, bv 14-16; genua 5-6; l" 23-25; tibiae 8-9, l' 6-8; tarsi 78, solenidia 10-11, empodia 8-10, 6-rayed, $\mathrm{ft}^{\prime}$ 27-28, ft" 28-30, u' 8-11. Legs II 30-32; femora 9-11, bv 14-18; genua 3-5, 1 " absent; tibiae 5-7; tarsi 6-8, solenidia 10-12, empodia 9-11, 6-rayed, $\mathrm{ft}^{\prime}$ 10-12, ft" 25-28, u' 8-9. Coxae: coxal setae I (1b) 8-11, 15-17 apart; coxal setae II (1a) 20-28, 10-11 apart; coxal setae III (2a) 55-58, 28-30 apart. Coxigenital area with 7-9 annuli, microtuberculate. Genitalia 21-22 wide, 13-17 long, granulated. Genital setae (3a) 59-63. Opisthosoma: $c 2$ 66-82, on annulus 1-2; $d 66-76,44-51$ apart, on annulus 15-16; e 54-61, 24-29 apart, on annulus 33-36; f 40-47, 24-28 apart, on annulus 56-61 or 9th from rear. Total dorsal annuli 58-65, total ventral annuli $65-69 ;$ h2 74-106, h1 absent.

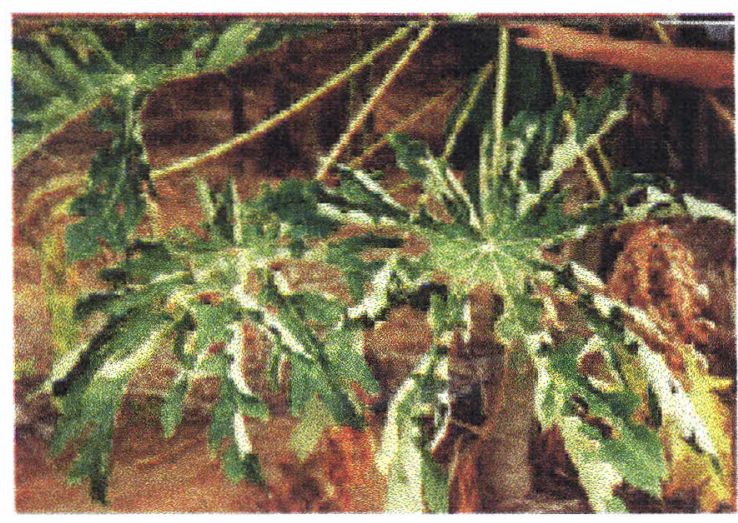

FIGURE 2. Papaya leaves damaged by Calacarus flagelliseta n.sp.

TYPE MATERIAL - female holotype, 37 female and 34 male paratypes, from Carica papaya L. (Caricaceae), Petrolina, Pernambuco, Brasil, coll. Flávia R.B. Moreira, 30 March 2001, on 17 microscopic preparations in the collection of Departamento de Entomologia, Fitopatologia e Zoologia Agrícola, Universidade de São Paulo, ESALQ, Piracicaba, São Paulo, Brasil.

RELATION TO HOST - upward curling of leaves, drying and necrosis

ETYMOLOGY - The specific designation flagelliseta refers to the relatively long ventral opisthosomal setae of this species.

REMARKS - In the prodorsal shield design C. flagelliseta is similar to $C$. citrifolii Keifer, 1955, C. brionesae Keifer, 1963 and C. speciosissimum Flechtmann, 2000, differing in the absence of the median section of the median line, fewer dorsomedian cells and the better defined lateral cells. Prodorsal shield tubercles are missing in the new species and in C. citrifolii, but present in C. brionesae. The new species is also a much larger mite than the last two mentioned species (idiosoma 220-246 long in the new species, 185-200 in C. citrifolii and 175-185 in C. brionesae). The empodia are 6-rayed in the new 
species, while 4-rayed in C. brionesae and 5-rayed in C. citrifolii and C. speciosissimum. The ventral setae are much longer in the new species, mainly the genital setae (3a) (56-65 in the new species, 18 in C. brionesae and C. citrifolii and 14-17 in C. speciosissimum); ventral setae I $(d)$ (77-89 in the new species, 75 in C. brionesae, 45 in C. citrifolii and 5979 in C. speciosissimum); ventral setae II (e) (54-63 in the new species 33 in C. brionesae, 40 in C. citrifolii and 24-31 in C. speciosissimum) and ventral setae III $(f)(37-48$ in the new species, 29 in C. brionesae, 25 in C. citrifolii and 31-35 in C. speciosissimum).

\section{References}

Flechtmann, C.H.W., Kreiter, S., Etienne, J. \& Moraes, G.J. de (2000) Plant mites (Acari) of the French Antilles. 4. Eriophyidae (Prostigmata). Acarologia, 40(3), 321-342.

Jeppson, L.R., Keifer, H.H. \& Baker, E.W. (1965) Mites Injurious to Economic Plants. University of California Press, Berkeley, 614 pp.

Keifer, H.H. (1940) Eriophyid Studies X. Bulletin of the California Department of Agriculture, 29(3), 160-179.

Keifer, H.H. (1955) Eriophyid Studies XXIII. Bulletin of the California Department of Agriculture, 44(3), 126-130.

Keifer, H.H. (1963) Eriophyid Studies B-9. California Department of Agriculture, Bureau of Entomology, 20 pp.

Meyer, M.K.P.S. \& Craemer, C. (1999) Mites (Arachnida: Acari) as crop pests in southern Africa: an overview. African Plant Protection, 5 (1), 37-51.

van der Merwe, G.G. \& Coates, T.J. (1965) Biological study of the grey mite, Calacarus citrifolii Keifer. South African Journal of Agricultural Science, 8, 817-823. 